\title{
Morning Glory Syndrome in Two (02) Malians: Case Report from IOTA-University Hospital
}

\section{Seydou Bakayoko*, Brainima Coulibaly, Mohamed Kolé Sidibe, Elien Gyrr* 모, Modibo Sissoko, Gounon Saye, Marcel Tembely, Fatoumata Sylla}

Institute of Africa Tropical Ophtalmology, University Hospital/University of Sciences, Technology of Bamako, Bamako, Mali Email: *toskanya@yahoo.fr, ${ }^{\star}$ rodrigueelien@yahoo.fr

How to cite this paper: Bakayoko, S., Coulibaly, B., Sidibe, M.K., Gyrr, E., Sissoko, M., Saye, G., Tembely, M. and Sylla, F. (2020) Morning Glory Syndrome in Two (02) Malians: Case Report from IOTA-University Hospital. Open Journal of Ophthalmology, 10, 255-259.

https://doi.org/10.4236/ojoph.2020.103027

Received: June 30, 2020

Accepted: August 25, 2020

Published: August 28, 2020

Copyright $\odot 2020$ by author(s) and Scientific Research Publishing Inc. This work is licensed under the Creative Commons Attribution International License (CC BY 4.0).

http://creativecommons.org/licenses/by/4.0/

\begin{abstract}
Background: First described by Handmann in 1929, the "Morning Glory Syndrome" is a rare congenital anomaly of the optic papilla whose notable ophthalmoscopic sign is papillary excavation associated with other ocular and/or non-ocular anomalies. Purpose: The main purpose of this study is to report 2 cases of this rare congenital papilla anomaly in 2 young Malian adults diagnosed in the IOTA-University Hospital respectively in January and May 2020. Materials and methods: In our study, we have included two cases of male gender. Results: In the $1^{\text {st }}$ case the defect concerned both papillae. It is also associated with other ocular malformations (bilateral macular reshaping and unilateral cataract), without associated cerebral defects. In the $2^{\text {nd }}$ case, only one papilla was affected by the malformation and there was an absence of associated malformations of other ocular and cerebral structures. Discussion: The Morning Glory Syndrome is part of the group of congenital defects of the optic nerve. It is often referred to as ectasia coloboma of the optical papilla or bindweed flower-like optical papilla because of its similarity to the tropical flower known as "bindweed". Its exact pathogenesis remains unknown, but it is linked to the poor development of the posterior sclera and lamina cribrosa during gestation. Conclusion: Morning Glory Syndrome through papillary excavation and other associated ocular and/or cerebral malformations may be a threat to vision.
\end{abstract}

\section{Keywords}

Morning Glory Syndrome, Congenital Papilla Defects, Bamako

\section{Introduction}

Handmann in 1929, based on a series of six observations of fundus anomalies, 
described a congenital optical papilla defect which he described as "a major degeneration, probably congenital, of the optic nerve with particular involvement of the central vessels" [1]. Later, Rieger (1977) and Pau (1980) corroborated Handmann's description of other patients [1]. It was not until Kindler presented a similar case in 1970 that the name "morning-glory syndrome" was attributed to this congenital optical papilla malformation [1]. Since then, several authors have reported different variants of this congenital optical papilla defect in Europe [1] [2] [3] and Africa [4] [5].

\section{Purpose of the Study}

The main purpose of our study is to present our experience on the managing of Morning Glory syndrome in those cases when Morning Glory syndrome causes functional impairment to the patient.

\section{Materials and Methods}

In our the study we have included two cases of the male gender, one with bilateral Morning Glory Syndrom (in both eyes) while the other with a mono lateral Morning Glory Syndrom (only in one eye). The treatment was optical.

\section{Results}

\subsection{Case 1}

Male patient 21 years old, who requested a medical examination at the IOTA-University Hospital, for progressive bilateral visual deterioration since childhood, worsening one year before his first consultation at the CHU-IOTA. His personal pathological history, ante, per, and postnatal were without particularities. The patient was the 2 nd child of a sibling of 4 children, all in good ocular health and from non-consanguineous marriage. At the time of his admission to the CHU-IOTA, his distance visual acuity was $1 / 10$ snelen line right eye improvable at the pinhole, 0.3 without correction and 0.5 with best-correction left eye. Biomicroscopic examination of the adnexae and structures of the anterior segment was normal in the right eye, in the left eye there was subcapsular opacity of the posterior lens. The intraocular pressure measured by the tonometer at applanation was $12 \mathrm{mmHg}$ on the right eye and $14 \mathrm{mmHg}$ on the left eye. The funduscopy showed wide excavation of the optic papilla on both eyes, with the excavation appearing larger on the right eye. At the peri-papillary level, a slightly prominent pigmented ring of subretinal tissue was visible, from which membrane-like radial bundles extended along most of the retinal vessels. An increased number of retinal vessels were visible at the edge of the papilla. The caliber of the retinal vessels was shrinking, with the macula showing changes in both eyes. This ophthalmoscopic aspect of the papilla led to the morning-glory syndrome. The patient was referred to neurology for associated neurological abnormalities, which concluded that there were no abnormalities in the brain structures. 
His objective refraction was as follows:

OD: Plan OG: $-0.75(-2.50) 5^{\circ}$ (See Figure 1).

\subsection{Case 2}

A 35-year-old man came to IOTA-University Hospital with a history of deteriorated vision in his right eye since childhood with no personal or family history of eye disease or congenital malformations. On examination, he had no facial malformation. The best-corrected distance visual acuity was the finger count at 0.5 meters in the left eye and 9/10 snellen line in the right eye. The refraction was plane in the left eye and $-1.25(-3.50) 62^{\circ}$ in the right eye. There was no nystagmus, but 10 diopter of esotropia with normal ocular motility. The examination of the anterior segment was normal in both eyes with normotonia. Examination of the fundus of the right eye was normal (Figure 2(a) and Figure 2(b)), that of the

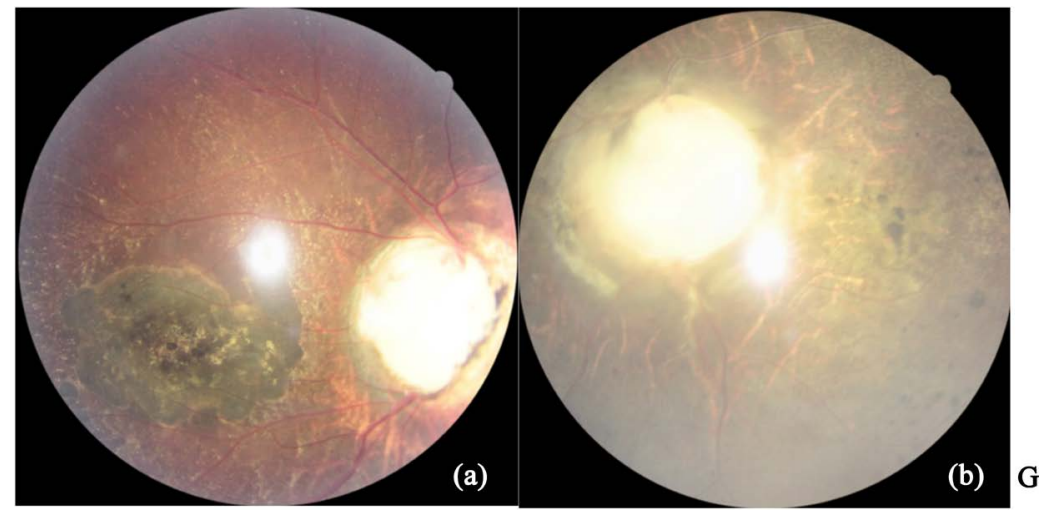

Figure 1. (a) Morning Glory Syndrome with small vessels and deep macular reshaping of the right eye. (b) Morning Glory Syndrome with small vessels, macular reshaping and progressive cataract (blurred picture) of the left eye.
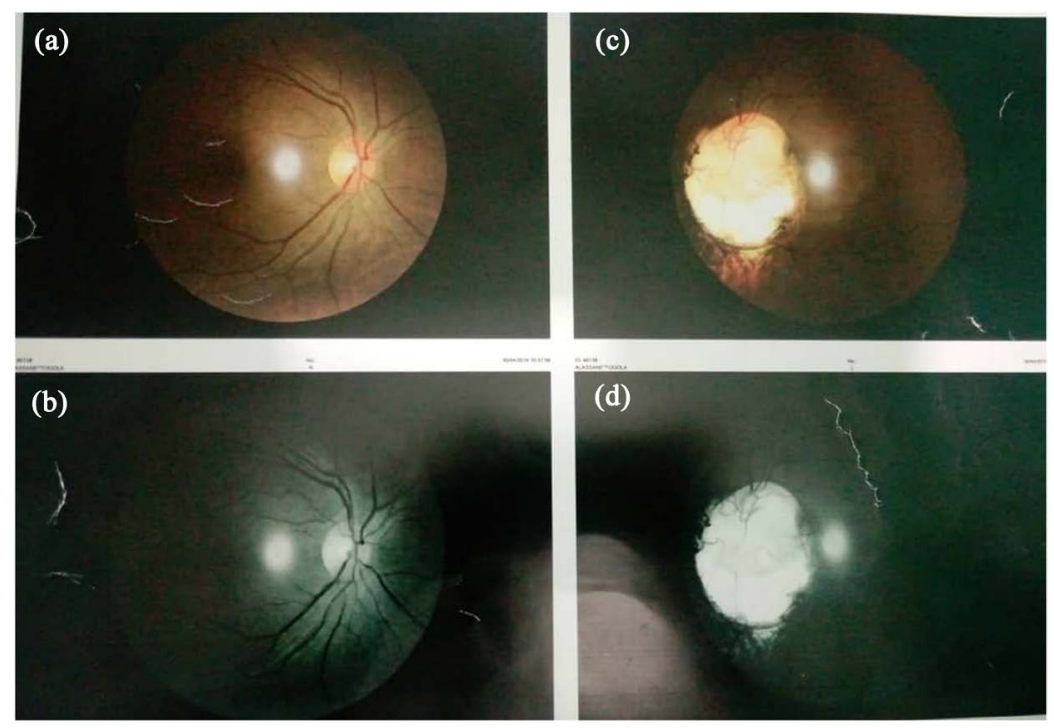

Figure 2. (a) and (b) Normal fundus image of the right eye. (c) Morning Glory Syndrome of the left eye (d) anerythrist film showing hyperfluorescence of the left eye papilla relative to Morning Glory Syndrome. 
left eye showed a huge excavated disc with a central turf of glial tissue and peripapillary chorioretinal pigmentation. The blood vessels were super numerical and radially ventilated from the disc (Figure 2(c) and Figure 2(d)). Neurological examination for associated brain malformations was normal.

\section{Discussion}

The Morning Glory Syndrome is a rare birth defect that affects the optic nerve head and several organs [4]. The genes involved are not yet known [5]. The exact pathogenesis of the morning-glory syndrome was not well established [5]. The excavation would occur either as a result of improper closure of the embryonic fissure during the $6^{\text {th }}$ week of intrauterine life, or as a result of a primary defect of the mesenchymal tissue leading to scleral, vascular and central glia malformations and thus takes on the appearance of a variant optic nerve coloboma [5].

The characteristic ophthalmoscopic aspect of the excavation of the optic papilla observed in the Morning Glory syndrome helps in its clinical diagnosis. It is a large funnel-shaped papillary excavation, interesting for the entire optic disc with a central region of white glial tissue and peripapillary chorioretinal pigmentation. The blood vessels are narrowed and radially arranged as we observed in the fundus examinations in both our patients [3] [4] [5] [6].

The Morning Glory Syndrome is usually unilateral, the bilateral form is rare [6]. We had a rare case of bilateral involvement in our first patient, and a case of unilateral involvement in the second patient.

The Morning Glory Syndrome can be isolated or associated with abnormalities of certain ocular structures (Coloboma of the crystalline lens, persistent vitreous hyperplasia) [5], sphenopharyngeal meningoencephalocele [5], frontonasal dysplasia [5] and Coats' disease [5], agenesis of the corpus callosum, microphthalmia [5].

In our two clinical cases, we observed the Morning Glory Syndrome Associated with other ocular abnormalities (macular reshaping and cataract) in the $1^{\text {st }}$ case and an isolated case of the Morning Glory Syndrome in the $2^{\text {nd }}$ patient.

Visual impairment in the Morning Glory Syndrome is variable, with distance visual acuity ranging from normal vision to light perception. And the refractive error is most often of the myopic type [6] [7].

In both our cases, the refractive errors were myopic astigmatism.

\section{Conclusion}

The purpose of this work is to highlight the possibility of a rare bilateral impairment and to emphasize the severe impairment of visual function in the Morning Glory.

\section{Conflicts of Interest}

The authors declare no conflicts of interest regarding the publication of this paper. 


\section{References}

[1] Nagy, V., Kettesy, B., Toth, K., Vamosi, P., Damjanovich, J. and Berta, A. (2002) Die Klinik des Morning-Glory-Syndroms. Klinische Monatsblätter Für Augenheilkunde, 219, 801-805. https://doi.org/10.1055/s-2002-36322

[2] Kouassi, F.X., Koman, C.E., Diomandé, I.A., Somahoro, M., Sowagnon, T.Y.C., Kra, A.N.S., and Koffi, K.V. (2017) Morning Glory Syndrome: A Case Report. Journal of Ophthalmology, 2, 000129. https://doi.org/10.23880/OAJO-16000129

[3] Loudot, C., Fogliarini, C., Baeteman, C., Mancini, J., Girard, N. and Denis, D. (2007) Rééducation de la part fonctionnelle de l'amblyopie dans un Morning Glory syndrome. Journal Français D’ Ophtalmologie, 30, 998-1001. https://doi.org/10.1016/S0181-5512(07)79276-8

[4] Napo Abdoulaye et Sidibe Mohamed Kolé (2017) Le syndrome du soleil levant. Pan African Medical Journal, 26, 176. https://doi.org/10.11604/pamj.2017.26.176.11445

[5] Osaguona, V.B. and Momoh, R.O. (2017) Morning Glory Syndrome in a Nigerian: A Case Report. Journal of the West African College of Surgeons, 7, 128-134. https://www.ncbi.nlm.nih.gov/pmc/articles/PMC6018034/pdf/morning-07-128.pdf

[6] Dedhia, C.J., Gogri, P.Y. and Rani, P.K. (2016) Rare Bilateral Presentation of Morning Glory Disc Anomaly. BMJ Case Reports, 2016, bcr2016215846. https://doi.org/10.1136/bcr-2016-215846

[7] Ceynowa, D.J., Wickström, R., Olsson, M., Ek, U., Eriksson, U., Wiberg, M.K. and Fahnehjelm, K.T. (2015) Morning Glory Disc Anomaly in childhood: A Population-Based Study. Acta Ophtalmologica, 93, 626-634.

https://doi.org/10.1111/aos.12778 